\title{
Ore Deposits and Metallogenesis of Tasmania
}

Mineral Resources Tasmania, PO Box 56, Rosny Park, Tasmania 7018, Australia.E-mail: ggreen@mrt.tas.gov.au

Tasmania contains a broad variety of economic mineral deposits, which includes several that have been known for over a century and are still operating today or were worked in the recent past. The Arthur Lineament, a belt of allochthonous amphibolite, carbonate rocks, psammite and pelite in northwest Tasmania hosts the Savage River magnetite deposit, which is now considered to be a Proterozoic carbonate replacement deposit with affinities to Kiruna-style iron-oxide $\mathrm{Cu}$-Au deposits. The allochthon was formed during an early Cambrian collisional event between an east-facing passive margin sequence and an intraoceanic island arc. Post collisional, proximal submarine volcanism at c. 500 Ma in the Mount Read Volcanics followed and associated mineralisation includes world-class deposits. High grade $\mathrm{Zn}-\mathrm{Pb}-\mathrm{Au}-\mathrm{Ag}$ Cu massive sulfide deposits (e.g., Rosebery and Hellyer) were formed from seawater-dominated hydrothermal fluids. Disseminated Cu-Au-Ag deposits of the Mount Lyell field are associated with broad alteration zones that include phyllosilicate assemblages indicative of a component of oxidised magmatic fluid, as does the Henty $A u$ deposit in the north. Orogenic Au is an important deposit style in northeast Tasmania and includes the Tasmania deposit, Australia's largest single Au reef. Largely post-orogenic granitic magmatism (Lower Devonian-Tournaisian) includes an important $S n-W$ base metal \pm magnetite mineralising event associated with reduced, fractionated granite in northeast and western Tasmania. World class $\mathrm{Sn} \pm \mathrm{Cu}$ sulfide skarn and vein deposits are the product of interpreted magmatic fluids exsolved from these granitic magmas. The highly unusual disseminated Avebury Ni deposit is associated with granite of this type. World class scheelite skarn deposits on King Island lie in the contact aureole of moderately oxidised, unfractionated Tournaisian granodiorite on King Island.

\section{Introduction}

Despite an area of only $68,000 \mathrm{~km}^{2}$, Tasmania has a remarkable geological diversity and abundance of mineral deposits. Rocks from every period of the Earth's history from the Mesoproterozoic are present and there have been at least four major episodes of economic mineralisation. Significant mineral deposits include Proterozoic magnetite, silica, dolomite and magnesite deposits; Cambrian VHMS base metal-Au and ultramafic-related Pt-group minerals (PGM) and chromite deposits; Devonian orogenic and intrusion related $\mathrm{Au}$ deposits; Middle Devonian-Tournaisian granite-related Sn, W, fluorite, magnetite, Ag- $\mathrm{Pb}-\mathrm{Zn}$ and $\mathrm{Ni}$ deposits; Triassic coal and Oligocene-Miocene lignite deposits; and Cenozoic alluvial Au, Sn and PGM deposits, and residual $\mathrm{Ni}-\mathrm{Co}, \mathrm{Fe}$ oxide, silica and clay deposits. Resource data are listed in Table 1.

This contribution is abbreviated from Seymour et al., (2006; revised 2007), but updated.

\section{Proterozoic}

The oldest known rocks in Tasmania are metaturbidites on King Island, metamorphosed at c. $1300 \mathrm{Ma}$ (Berry et al., 2005) and, with youngest detrital zircons dated at $1350 \mathrm{Ma}$ (Black et al., 2004). In northwestern and central Tasmania quartz arenite, siltstone, shale (commonly carbonaceous and pyritic) and minor carbonate rocks of the Rocky Cape Group and Tyennan region respectively, thought to be of late Mesoproterozoic-Neoproterozoic age, were deposited in a passive margin marine shelf environment (Figure 1). Between these occurs a quartzwacke turbidite formation of roughly similar age (Burnie and Oonah formations), but slightly better constrained to c. 1070-750 Ma (Calver et al., 2012). These successions are overlain by Cryogenian-Terreneuvian carbonates, siliciclastics (including glacigene diamictite) and dominantly mafic volcanics. These volcanics include c. 580 Ma syn-rift tholeiites, which represent a probably Efacing continental margin (Ps in Figure 1; Calver et al., 2012). The carbonates are an important host to Devonian $\mathrm{Sn}, \mathrm{W}, \mathrm{Cu}$ and magnetite skarn mineralisation on King Island, and at Mt Bischoff, Mt Lindsay, Renison Bell and elsewhere in western Tasmania. High purity silica flour deposits are interpreted as disaggregated silicified Neoproterozoic dolomite. Gabbro dykes of probable Neoproterozoic age host minor, but locally high grade, Ni-Cu-Pt-Pd-Au mineralisation in the Cuni district, near Zeehan.

Separating the two sequences on King Island is an unconformity related to the Wickham Orogeny, with syn-orogenic granite dated at c. $760 \mathrm{Ma}$ (Turner et al., 1998). On mainland Tasmania the boundary is marked by a mild deformational event and locally low angle unconformity.

\section{Cambrian Orogenesis, ultramafics, the Arthur Lineament and associated mineralisation}

The major collisional Tyennan Orogeny occurred between c. 512 $506 \mathrm{Ma}$ (Turner et al., 1998), contemporaneous with the first phase 
Table 1 Non-alluvial deposits of Tasmania: pre-mining resources

Note: These data rely on past production figures and various resource estimations. Some of the latter do not comply with the Joint Ore Reserves Committee Code standards.

\begin{tabular}{ll}
\hline Precambrian deposits in the Arthur Lineament \\
Savage River & $371 \mathrm{Mt} @ 31.9 \% \mathrm{Fe}$ \\
Arthur River & $29 \mathrm{Mt} @ 42.8 \% \mathrm{Mg}$ \\
Main Creek & $42.8 \mathrm{Mt} @ 42.4 \% \mathrm{Mg}$ \\
\hline Cambrian gabbro-hosted deposits \\
Nickel Reward & $0.03 \mathrm{Mt} @ 3 \% \mathrm{Ni}$ \\
(Cuni field) & \\
North Cuni-Genets & $0.95 \mathrm{Mt} @ 0.76 \% \mathrm{Ni}, 0.94 \% \mathrm{Cu}$ \\
Winze & \\
\hline Cambrian deposits in the Mount Read Volcanics \\
Hellyer & $16.5 \mathrm{Mt} @ 13.9 \% \mathrm{Zn}, 7.2 \% \mathrm{~Pb}$, \\
& $0.38 \% \mathrm{Cu}, 169 \mathrm{~g} / \mathrm{t} \mathrm{Ag}, 2.55 \mathrm{~g} / \mathrm{t} \mathrm{Au}$ \\
Fossey Zone & $0.55 \mathrm{Mt} @ 0.5 \% \mathrm{Cu}, 7.1 \% \mathrm{~Pb}$, \\
& $12.9 \% \mathrm{Zn}, 134 \mathrm{~g} / \mathrm{t} \mathrm{Ag}, 2.6 \mathrm{~g} / \mathrm{t} \mathrm{Au}$ \\
Que River & $3.3 \mathrm{Mt} @ 13.3 \% \mathrm{Zn}, 7.4 \% \mathrm{~Pb}$, \\
& $0.7 \% \mathrm{Cu}, 195 \mathrm{~g} / \mathrm{t} \mathrm{Ag}, 3.3 \mathrm{~g} / \mathrm{t} \mathrm{Au}$ \\
Mount Charter & $6.1 \mathrm{Mt} @ 0.5 \% \mathrm{Zn}, 25.5 \mathrm{~g} / \mathrm{t} \mathrm{Ag}$, \\
& $1.22 \mathrm{~g} / \mathrm{t} \mathrm{Au}, 9.7 \% \mathrm{Ba}$ \\
Rosebery & $46.70 \mathrm{Mt} @ 12.46 \% \mathrm{Zn}, 3.9 \% \mathrm{~Pb}$, \\
& $0.50 \% \mathrm{Cu}, 133 \mathrm{~g} / \mathrm{t} \mathrm{Ag}, 1.93 \mathrm{~g} / \mathrm{t} \mathrm{Au}$ \\
Hercules & $3.33 \mathrm{Mt} @ 17.3 \% \mathrm{Zn}, 5.5 \% \mathrm{~Pb}$, \\
& $0.4 \% \mathrm{Cu}, 171 \mathrm{~g} / \mathrm{t} \mathrm{Ag}, 2.8 \mathrm{~g} / \mathrm{t} \mathrm{Au}$ \\
South Hercules & $0.56 \mathrm{Mt} @ 3.7 \% \mathrm{Zn}, 1.9 \% \mathrm{~Pb}$, \\
& $0.1 \% \mathrm{Cu}, 157 \mathrm{~g} / \mathrm{t} \mathrm{Ag}, 3.0 \mathrm{~g} / \mathrm{t} \mathrm{Au}$ \\
Henty-Mt Julia & $2.83 \mathrm{Mt} @ 12.5 \mathrm{~g} / \mathrm{t} \mathrm{Au}$ \\
Tasman and Crown Lyell & $0.138 \mathrm{Mt} @ 10.0 \% \mathrm{Zn}, 8.9 \% \mathrm{~Pb}$, \\
& $0.54 \% \mathrm{Cu}, 212 \mathrm{~g} / \mathrm{t} \mathrm{Ag}, 0.35 \mathrm{~g} / \mathrm{Au}$ \\
Mount Lyell & $311 \mathrm{Mt} @ 0.97 \% \mathrm{Cu}, 0.31 \mathrm{~g} / \mathrm{t} \mathrm{Au}$ \\
Garfield & $12 \mathrm{Mt} @ 0.3 \% \mathrm{Cu}$ \\
\hline
\end{tabular}

$\begin{array}{ll}\text { Ordovician carbonate-hosted deposits } \\ \text { Oceana } & 2.6 \mathrm{Mt} @ 7.7 \% \mathrm{~Pb}, 2.5 \% \mathrm{Zn}, \\ & 55 \mathrm{~g} / \mathrm{t} \mathrm{Ag} \\ \text { Grieves Siding } & \sim 0.7 \mathrm{Mt} @ 8 \% \mathrm{Zn} \text { (primary); } \\ & 0.15 \mathrm{Mt} @ 5 \% \mathrm{Zn} \text { (secondary) }\end{array}$

\begin{tabular}{ll}
\hline Devonian orogenic Au deposits & \\
Beaconsfield & $3.25 \mathrm{Mt} @ 19.0 \mathrm{~g} / \mathrm{t} \mathrm{Au}$ \\
New Auen Gate & $0.51 \mathrm{Mt} @ 15.6 \mathrm{~g} / \mathrm{t} \mathrm{Au}$ \\
Pinafore Reef (Lefroy) & $0.974 \mathrm{Mt} @ 10.1 \mathrm{~g} / \mathrm{t} \mathrm{Au}$
\end{tabular}

$\begin{array}{ll}\text { Devonian granite-related Sn deposits } \\ \text { Sulfide skarns } \\ \text { Renison Bell } & 30.03 \mathrm{Mt} @ 1.44 \% \mathrm{Sn} ; \\ & 1.93 \mathrm{Mt} @ 0.35 \% \mathrm{Cu} \\ \text { Mount Bischoff } & 10.54 \mathrm{Mt} @ 1.1 \% \mathrm{Sn} \\ \text { Cleveland } & 12.4 \mathrm{Mt} @ 0.61 \% \mathrm{Sn}, 0.25 \% \mathrm{Cu} \\ \text { Foley zone } & 3.8 \mathrm{Mt} @ 0.28 \% \mathrm{WO}_{3}, 0.02 \% \mathrm{MoS}_{2}, \\ & 0.05 \% \mathrm{Sn} \\ \text { Razorback } & 0.34 \mathrm{Mt} @ 0.9 \% \mathrm{Sn} \\ \text { Queen Hill } & 4.36 \mathrm{Mt} @ 1.1 \% \mathrm{Sn} \\ \text { Silicate skarns } & \\ \text { St Dizier } & \sim 2.6 \mathrm{Mt} @ 0.5 \% \mathrm{Sn}, 0.05 \% \mathrm{WO}_{3} \\ \text { Magnetite skarns } & \\ \text { Mount Lindsay } & 18 \mathrm{Mt} @ 0.3 \% \mathrm{Sn}, 0.2 \% \mathrm{WO}_{3}, \\ & 17 \% \mathrm{recoverable} \mathrm{Fe} \\ \text { Nelson Bay River } & 12.7 \mathrm{Mt} @ 36.1 \% \mathrm{Fe} \text { (includes } \\ \text { secondary hematite ore) } & \end{array}$

Table 1 Contd...

\begin{tabular}{ll}
\hline Vein deposits & \\
Aberfoyle & $2.1 \mathrm{Mt} @ 0.91 \% \mathrm{Sn}, 0.28 \% \mathrm{WO}_{3}$ \\
Pieman vein (East Renison) & $0.43 \mathrm{Mt} @ 1.0 \% \mathrm{Sn}$ \\
Greisen deposits & \\
Anchor & $2.39 \mathrm{Mt} @ 0.28 \% \mathrm{Sn}$ \\
\hline Other Devonian granite-related deposits \\
$\begin{array}{l}\text { Skarns } \\
\text { King Island field }\end{array}$ & $23.8 \mathrm{Mt} @ 0.66 \% \mathrm{WO}_{3}$ \\
Kara & $5.2 \mathrm{Mt} @>30 \% \mathrm{Fe}, \mathrm{by}-\mathrm{product} \mathrm{WO}_{3}$ \\
Avebury & $10.04 \mathrm{Mt} @ 1.14 \% \mathrm{Ni}$ \\
Moina & $18 \mathrm{Mt} @ 26 \% \mathrm{CaF}, 0.1 \% \mathrm{Sn}, 0.1 \% \mathrm{WO}_{3}$ \\
Hugo (Moina area) & $0.25 \mathrm{Mt} @ 5.5 \% \mathrm{Zn}, 1 \mathrm{~g} / \mathrm{t} \mathrm{Au}, 0.1 \% \mathrm{Bi}$ \\
Stormont (Moina area) & $0.135 \mathrm{Mt} @ 3.44 \mathrm{~g} / \mathrm{t} \mathrm{Au}, 0.21 \% \mathrm{Bi}$ \\
Vein deposits & \\
Storeys Creek & $1.1 \mathrm{Mt} @ 1.09 \% \mathrm{WO}, 0.18 \% \mathrm{Sn}$ \\
Magnet & $0.63 \mathrm{Mt} @ 7.3 \% \mathrm{Zn}, 7.3 \% \mathrm{~Pb}, 427 \mathrm{~g} / \mathrm{t} \mathrm{Ag}$ \\
Salmons Vein & $0.83 \mathrm{Mt} @ 3.2 \% \mathrm{~Pb}, 2.2 \% \mathrm{Zn}$, \\
(East Renison) & $104 \mathrm{~g} / \mathrm{t} \mathrm{Ag}, 0.19 \% \mathrm{Sn}, 0.61 \% \mathrm{Cu}$ \\
New North Mount Farrell & $0.908 \mathrm{Mt} @ 12.5 \% \mathrm{~Pb}, 2.5 \% \mathrm{Zn}$, \\
and North Mount Farrell & $408 \mathrm{~g} / \mathrm{t} \mathrm{Ag}$ \\
Lakeside & $0.75 \mathrm{Mt} @ 0.2 \% \mathrm{Sn}, 0.2 \% \mathrm{Cu}$, \\
& $4.0 \% \mathrm{As}, 2.1 \mathrm{~g} / \mathrm{t} \mathrm{Au}, 20 \mathrm{~g} / \mathrm{t} \mathrm{Ag}$ \\
\hline Paleocene residual deposits & \\
Barnes Hill & $6.6 \mathrm{Mt} @ 0.82 \% \mathrm{Ni}, 0.06 \% \mathrm{Co}$ \\
\hline & \\
\hline &
\end{tabular}

of the Delamerian Orogeny on the Australain mainland, and is believed to by related to NE-directed subduction of the thinned Tasmanian Precambrian crust beneath an intraoceanic island arc (Meffre et al., 2000). Dismembered mafic-ultramafic complexes including oceanic forearc boninites, low-Ti tholeiites, gabbros, and orthopyroxene-rich ultramafic cumulates (Brown and Jenner, 1989) were obducted onto the craton (Berry and Crawford, 1988). A tonalite from one of the complexes has been dated at $513.6 \pm 5.0 \mathrm{Ma}$ (Black et al., 1997), providing an upper limit on the age of the alllochthon. Other sedimentary sequences, including deep marine chert, are considered part of the allochthonous units. Osmiridium is associated with the ultramafics rocks and derived alluvial deposits were the focus of a small industry during 1910-1959.

In central and western Tasmania there was locally strong deformation of the Proterozoic rocks with two phases of recumbent folding and metamorphism up to eclogite facies. The western boundary of the strong deformation and higher grade metamorphism is defined by the Arthur Lineament (Figure 2), a narrow, $110 \mathrm{~km}$ long, NE striking belt of tholeiitic amphibolites, metasediments and carbonates, including significant diagenetic magnesite deposits of the Arthur Metamorphic Complex. Several magnetite deposits are associated with the lineament, including the major Savage River deposit. The Arthur Lineament includes deformed albitised intrusive rocks (?granodiorite) of Wickham Orogeny age (777 \pm 7 Ma; Turner et al., 1998). Similar rocks occur near the Savage River deposit and are considered to be part of the alteration assemblage associated with ore formation (Bottrill and Taheri, 2008). The central part of the Arthur Lineament, the Bowry Formation, is considered to be entirely allochthonous (Holm and Berry, 2002) and this is consistent with its unique mineralisation styles and the age of the intrusive.

The Savage River deposit consists of several lenses of magnetiterich ore with the following associated minerals in various proportions 


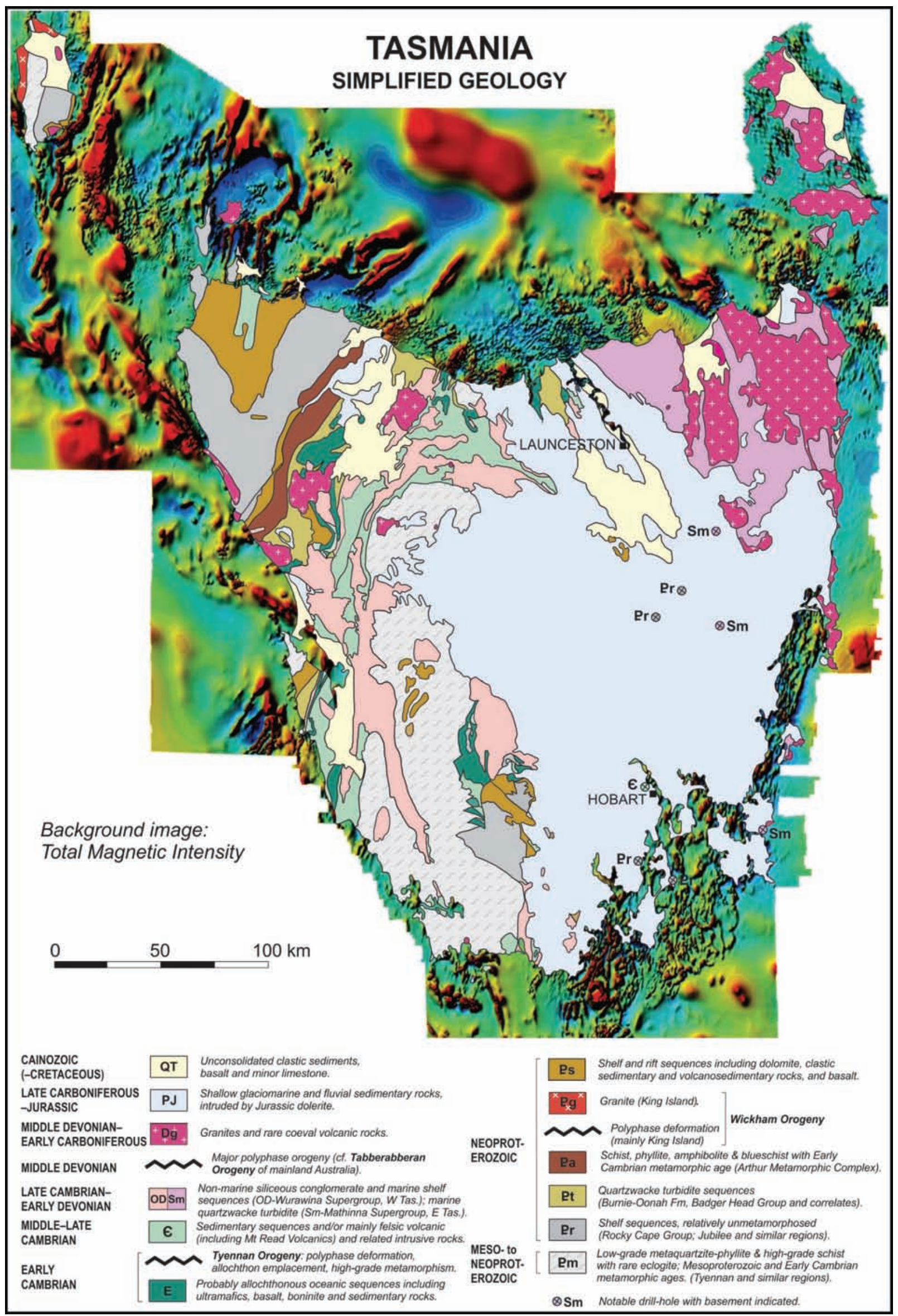

Figure 1 Simplified geology of Tasmania, with total magnetic image by R.G. Richardson in offshore area (from Seymour et al., 2006). 


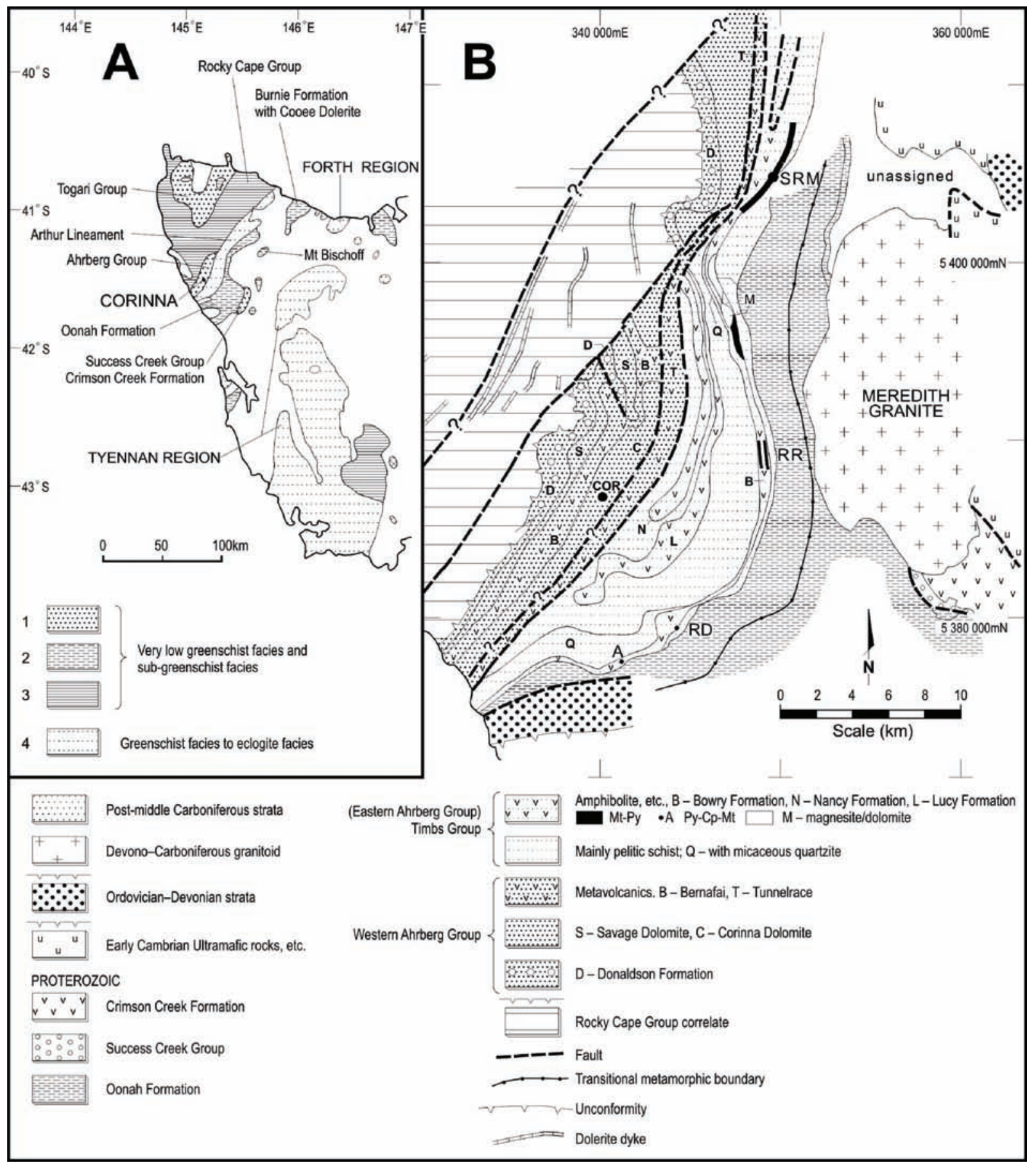

Figure 2 (A) Western Tasmania showing Proterozoic rocks (1 - continental shelf and margin deposits with rift tholeites near the top; 2 sandy turbidite; 3 - quartz arenite, siltstone, minor dolomite) and c. 515-510 Ma metamorphic rocks derived from Proterozoic rocks (4) (after Bottrill and Taheri, 2008). (B) Detailed geology of the Corinna district after Turner et al. (1991). The Arthur Metamorphic Complex consists of the Timbs Group and the adjacent, metamorphosed part of the Oonah Formation. The boundaries are defined by the tectonic feature called the Arthur Lineament (Gee, 1967) shown in Figure 2A. Abbreviations: COR=Corinna; SRM = Savage River mine; RR = Rocky River; RD = Reece Dam; A = Alpine locality.

in roughly decreasing maximum abundance: amphibole (dominantly tremolite-actinolite, but also relict hornblende and blue amphiboles including glaucophane and later barroisite-winchite-actinolite), serpentine, talc, dolomite, calcite, pyrite, chlorite, albite, quartz, apatite and hematite. Amphibolite, pyroxene-rich rocks, serpentinite, magnesite, talc-chlorite-quartz-dolomite schist, dolostone and mafic metasedimentary rocks are present within the host sequence and the ores and host rocks show strong deformational fabrics. Some minerals such as calcite and hematite are entirely retrogressive and post-date the two main Cambrian deformational events (Bottrill and Taheri, 2008). The serpentinite is notable in having insignificant Cr. The features of the deposit are consistent with hydrothermal replacement of carbonate and mafic host rocks predating or early in the deformational history of the area and have affinities with Kiruna- 
type iron-oxide $\mathrm{Cu}-\mathrm{Au}$ deposits (IOCG) deposits (Taheri and Bottrill, pers. comm., 2011). Trace quartz, rutile, titanite and chalcopyrite are present. Further south in the Bowry Formation, at the Alpine prospect, significant chalcopyrite is present within and near similar ironstone.

\section{Middle Cambrian post-collisional phase: Mt Read Volcanics}

The most important metallogenic event in Tasmania coincided with the deposition of the Mount Read Volcanics (MRV). U-Pb zircon ages and numerous fossil occurrences constrain the bulk of the MRV to c. 506-494 Ma (Corbett and Vicary, 2012). The main mineralised belt of the MRV between Mount Darwin and Hellyer is the Central Volcanic Complex (CVC), which is dominated by proximal felsic volcanic rocks (rhyolite and dacite flows, domes and cryptodomes and massive pumice breccias) and andesite and rare basalt (lavas, hyaloclastites and intrusive rocks) deposited in a marine environment (Corbett 1992; 2002; Gifkins and Kimber, 2003). This belt is flanked to the west by the coeval Western Volcano-Sedimentary Sequence (WVS) of turbidites with lithic sandstone and mudstone (commonly rich in shards), siltstone, shale and subordinate intrusive rocks and lavas, commonly andesitic (Corbett, 2002).

These rocks are overlain by the Tyndall Group, a unit of quartzbearing volcaniclastic sandstone and conglomerate, minor felsic and andesitic lavas and intrusive rocks and welded ignimbrite (White and McPhie, 1996). Considerable erosion took place locally before deposition of the Tyndall Group. Clasts of granite and altered volcanic rocks occur in the basal Tyndall Group in the Mount Darwin area (Corbett, 2002; Morrison, 2002).

Flanking the CVC to the east and abutting the metasedimentary rocks of central Tasmania is the Eastern Quartz-phyric Sequence, which consists mostly of quartz-feldspar-phyric lavas, intrusive porphyries and volcaniclastic sandstone, that are intruded by magnetite series granites. The base of this unit consists of Precambrian-derived sandstone and conglomerate which passes upward gradationally into volcaniclastic sandstone. There is uncertainty about whether the Eastern Quartz-phyric Sequence is a time equivalent of the CVC (Corbett, 2002) or part of the Tyndall Group (Murphy et al., 2004).

Tectonism was mostly near east-west extensional during Mount Read Volcanics deposition, as recorded by the orientation of hydrothermal veins (e.g., at the Hellyer deposit; Gemmell and Large, 1992) and basaltic dykes in the Henty Fault Zone. Further evidence of an extensional regime is provided by growth faulting and cauldron subsidence associated with the formation of the thick pumice-rich breccia underlying the Rosebery deposit (Green et al., 1981; Gifkins and Kimber, 2003). Solomon and Groves (2000) suggested that this episode of extensional tectonism and crustal thinning was related to eastward retreat of a west-dipping subduction zone following the 512506 Ma collisional event.

Mineralisation was concentrated in a short time interval in the late middle Cambrian at the top of the CVC and in places in the immediately overlying Tyndall Group rocks. Major alteration zones are dominantly of quartz-sericite mineralogy and restricted to the proximal CVC volcanic facies (Gifkins and Kimber, 2003; Herrmann and Kimber, 2003), but chlorite-rich cores are apparent at Hellyer (Gemmell and Large, 1992) and Hercules (Green and Taheri, 1992). Despite this association with the CVC, the WVS, in areas of andesite proximally underlying Tyndall Group equivalents, represent underexplored targets (Corbett, 2002).

The Henty Fault Zone constitutes a fundamental metallogenic divide within the MRV. To the northwest, polymetallic $\mathrm{Zn}-\mathrm{Pb}-\mathrm{Au}-$ Ag-Cu massive sulfide deposits dominate (Hellyer, Que River, Rosebery and Hercules; Figure 3) together with disseminated deposits with low base metal, but relatively high $\mathrm{Au}$ and $\mathrm{Ag}$, tenor (Mount Charter and South Hercules). Mount Charter is a barite-rich, lowgrade precious and base metal deposit formed within quartz-sericite altered volcanic rocks in an alteration system that presumably underlay a lower temperature white smoker exhalative hydrothermal vent field. Ore fluids have been considered to have been derived by convective circulation of seawater and interaction with volcanic and basement rocks, but there is evidence for a magmatic contribution to the ore fluids at Hellyer (Solomon and Groves, 2000). There is also debate about the extent to which massive sulfide ore deposition took place in brine pools on the seafloor (Solomon and Groves, 2000), as opposed to in either Kuroko-type hydrothermally reworked seafloor mounds (e.g., Gemmell and Large, 1992) or sub-seafloor replacement or displacement (Allen, 1995). There is clear evidence for sub-seafloor ore formation locally, e.g., at the Hercules deposit and Fossey Zone, immediately south of Hellyer.

Southeast of the Henty Fault $\mathrm{Cu}-\mathrm{Au}$ and $\mathrm{Au}$ deposits dominate, exemplified by the Mount Lyell field and the Henty Au deposit. The most economically important deposits in the Mount Lyell field are disseminated chalcopyrite-pyrite orebodies in alteration assemblages dominated by quartz-sericite or quartz-chlorite-sericite (Prince Lyell, Cape Horn, Lyell Comstock, in part, and Western Tharsis; Walshe and Solomon, 1981; Corbett, 2001). The Western Tharsis deposit consists of concentrically and vertically zoned alteration assemblages centred on the mineralisation, with a lower and central quartz-chloritesericite zone passing upward and outward in turn into pyritic quartzpyrophyllite \pm topaz \pm fluorite \pm zunyite \pm woodhouseite with local bornite-bearing zones and a pyritic quartz-sericite assemblage (Huston and Kamprad, 2001). The highest grade ores are in the North Lyell area and consist of coarse-grained bornite with chalcopyrite and minor pyrite in brecciated chert \pm pyrophyllite \pm barite \pm hematite or quartzsericite schist at or near the faulted contact between the altered CVC and the Owen Conglomerate, which may be locally hematised. The origin of these high-grade ores has been a subject for debate. Solomon et al. (1987) suggested that they may have formed during Devonian deformation by mixing of metamorphic fluids from the volcanic rocks and conglomerate, but most current opinion is that the ores of the field formed at the same early Tyndall Group time (Corbett, 2001; Huston and Kamprad, 2001). A Re-Os date of 500.4 \pm 2.3 Ma has been determined on molybdenite from Prince Lyell (Huston et al., 2009).

The first deposit mined, the Mount Lyell or Iron Blow deposit, consisted mostly of massive pyrite-chalcopyrite. There are also small lenses of polymetallic pyritic sphalerite-galena rich massive sulfide in the Lyell Comstock area at the northern end of the field. There are other disseminated $\mathrm{Cu}$ deposits in the CVC further south. Some, such as the Garfield prospect, appear geologically similar to Prince Lyell. A $475 \mathrm{~km}^{2}$ HyMap airborne hyperspectral survey flown over Mount Lyell showed that the main $\mathrm{Cu}$ deposits area is associated with $\mathrm{Al}-$ rich mica and that there is a zone of intense pyrophyllite-topaz alteration that may represent a significant exploration target at Glen Lyell, about $1 \mathrm{~km}$ south of the Prince Lyell orebody (Huntington and Cocks, 2003). 
The Henty Au mine (Figure 3) consists of a series of small high-grade lenses of Au mineralisation in quartz \pm sericite-altered volcaniclastic and volcanic rocks that occupy a large sub-vertical quartz-sericite alteration zone that transects the CVC-Tyndall Group contact at a low angle. The deposit is regarded as a submarine epithermal system formed from a magmatic fluid (Callaghan, 2001). Halley (2007) identified quartztopaz-pyrophyllite alteration in the footwall of the Mount Julia section of the deposit and invoked the mixing of $\mathrm{SO}_{2}$-rich magmatic and seawater derived fluids in the formation of the deposit. Current opinion also favours a significant or dominant magmatic component in the fluids that formed the Mount Lyell deposits (Large et al., 1996; Huston and Kamprad, 2001), with the fluids supposedly derived from Cambrian granitic magmas. The three dimensional geological model of Tasmania provides some empirical support for this, in that granite is interpreted to shallowly underlie the $\mathrm{Cu}-\mathrm{Au}$ metallogenic region east of the Henty Fault, but is considered to be at far greater depths to the west.

Positive evidence of undiscovered VHMS deposits in western Tasmania exists in the form of debris flow deposits with rafts and clasts of high-grade ore (Figure 3).

\section{Wurawina Supergroup: Upper Cambrian-Lower Devonian}

In the late Cambrian, the final phase of the Tyennan Orogeny inverted earlier extensional faults (e.g., Henty Fault). Major reverse faults and upright open northtrending folds were formed in western Tasmania. This phase also caused uplift of the Tyennan region, with syn-orogenic sediments (Owen Group) accumulating in a half graben, commonly with angular or erosional unconformity on older units. It typically includes large volumes of coarse siliciclastic conglomerate composed dominantly of metaquartzite clasts derived from the Proterozoic rocks to the east, but also includes turbidite and shallow marine sandstone units (Noll and Hall, 2005; Seymour et al., 2006).

In western Tasmania, the Gordon Group rests on the Owen Group with angular unconformity and consists of basal sandstone followed by a shallow-marine to peritidal, platform succession of predominantly micritic, dolomitic limestone that is up to $1.8 \mathrm{~km}$ thick in centralsouthern Tasmania but considerably thinner in western Tasmania. The onset of carbonate sedimentation took place in the Middle Ordovician in western and northern Tasmania but was earlier (Early Ordovician) in the east (Banks and Burrett, 1980; Banks and Baillie, 1989; Laurie, 1995). Stratiform sulfide mineralisation and an associated breccia unit in the Zeehan area, notably at the Oceana deposit, indicate local synsedimentary faulting and possible exhalative activity (Taylor and Mathison, 1990). Gordon Group carbonate sequences became an important ore host for skarn mineralisation associated with intrusion of Late Devonian-Tournaisian granites. High purity limestone is mined at Mole Creek for metallurgical use and limestone from
Railton and elsewhere is utilised for cement manufacture and other purposes.

The Gordon Group is overlain by the Silurian-Early Devonian Eldon Group comprised of shelf sandstone, shale and minor limestone (Banks and Baillie, 1989).

\section{Mathinna Supergroup: Ordovician- Early Devonian}

Deposition of the Mathinna Supergroup in eastern Tasmania was approximately coeval with deposition of the uppermost parts of the Owen Group to the top of the Eldon Group in western Tasmania. The Mathinna Supergroup comprises a succession of turbiditic sandstone and mudstone and forms the pre-Carboniferous sedimentary basement to eastern Tasmania. It consists of Ordovician sandstone, mudstone and pyritic black slate in fault contact with Silurian-Early Devonian 
sandstone and mudstone (Seymour et al., 2011). The oldest deformation event affecting the sequence was Late Ordovician-early Silurian (Benambran) and only affected the Ordovician formations (Reed, 2001).

$\mathrm{U}-\mathrm{Pb}$ analyses of detrital zircon indicate the source of the Mathinna Supergroup was not the Western Tasmanian terrane (Black et al., 2004). The current models suggest that northeastern Tasmania may have been substantially separated from the rest of Tasmania at the time of its deposition, and that it was finally docked with western Tasmania during Middle Devonian orogenesis (e.g., Black et al., 2010).

\section{Middle Devonian orogenesis, granite emplacement and mineralisation}

During the Middle Devonian, most of Tasmania was affected by polyphase deformation, characterised by a complexity of fold orientations, due in part to reactivation of older structures. The fold geometry was commonly controlled by the trends of Cambrian folds which were tightened during the Devonian, and as a result, in places Devonian cleavage orientations transect the axial planes of associated folds (Seymour et al., 2006).

The folding occurred in two main phases in western Tasmania. The early phase produced NNW-trending folds in areas where reactivation effects were not significant, and was followed by a second phase that produced NW- to WNW-trending folds and thrusts (Seymour et al., 2006).

The Mathinna Supergroup of NE Tasmania also shows evidence of two Devonian compressional deformation events, the last of which was WSW directed thrusting that accompanied orogenic $\mathrm{Au}$ mineralisation in the region (Powell, 1991; Reed, 2002, 2004), at c. $400 \mathrm{Ma}$ (Bierlein et al., 2005).

Sandstone, siltstone and conglomerate in the Beaconsfield area and the Mathinna Supergroup, further east, host economically important orogenic vein-style $\mathrm{Au}$ mineralisation, In the western part of the Eastern Tasmanian Terrane, notably in the Beaconsfield and Lefroy districts (Figure 4), steeply dipping reefs have an E-ENE orientation and formed nearparallel to the axis of maximum principal stress (Powell, 1991; Reed, 2002), whereas to the east along the Mangana-MathinnaWaterhouse Au lineament and elsewhere, the dominant orientation is NNW and orthogonal to this axis. The latter structures form as a response to failure on the steep eastern limbs of anticlines formed during the earlier fold event. In detail, Au-rich shoots within the reefs tend to pitch steeply, as a response to either favourable lithology for reef formation (Beaconsfield) or due to Au mineralisation during late transcurrent movement on the structures (Mathinna; Keele, 1994).

An extended period of large-scale granitic intrusion at relatively high crustal levels commenced in eastern Tasmania at c. 400 Ma with the emplacement of unfractionated I-type granodiorites. This occurred prior to the Devonian deformation events, and continued after the close of Devonian deformation, with the youngest intrusions at $\mathrm{c}$. $350 \mathrm{Ma}$ on King Island (Black et al., 2005). There is also one body of thick welded tuff (the St Marys Porphyrite), dated at $388 \pm 1 \mathrm{Ma}$ (Turner et al., 1986). Most of the western Tasmanian granitic rocks post-date Devonian folding events. On mainland Tasmania the granitic rocks form three large complexes; one in the east, another in the northwest (Figure 5), and a third largely concealed beneath the southwest corner of Tasmania. Dating reveals westward younging regionally across Tasmania, and there is also a compositional trend towards felsic, fractionated I-type and S-type granite and monzogranite with decreasing age (Black et al., 2005).

Important deposits of $\mathrm{Sn}, \mathrm{W}$ and lesser occurrences of $\mathrm{Ni}$, magnetite, $\mathrm{Cu}, \mathrm{Ag}, \mathrm{Pb}, \mathrm{Zn}$ and $\mathrm{Au}$ are associated with Devonian granite emplacement. All significant granite-related deposits lie within the 4 $\mathrm{km}$ granite isobath (Figure 5; Leaman and Richardson, 2003). Contrast in the host rocks in western and northeastern Tasmania is responsible for fundamental differences in the Late Devonian-early Carboniferous metallogenesis of the regions. There is a more restricted range of deposits in the northeast due mostly to a lack of reactive host

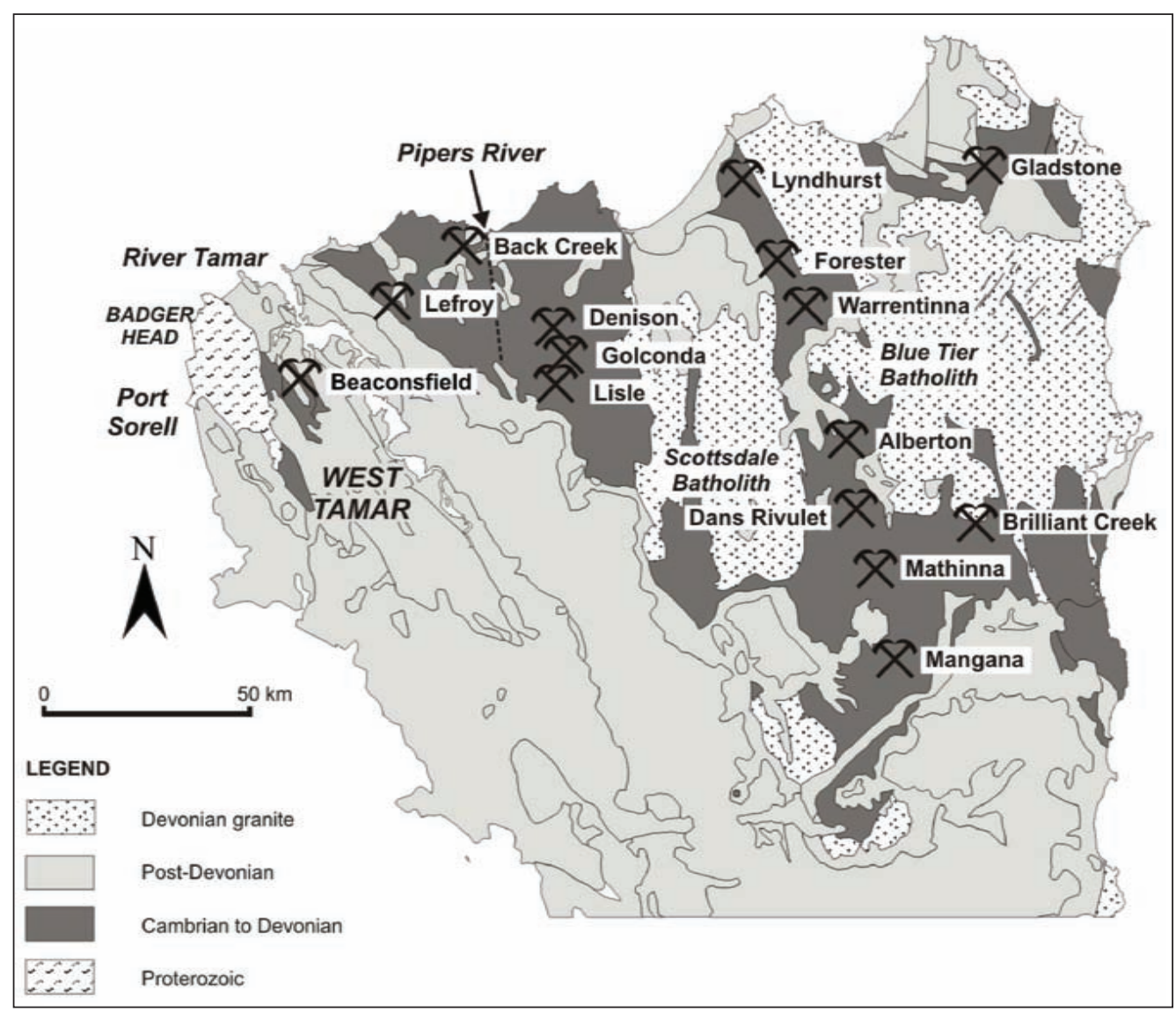

Figure 4 Location of goldfields in NE Tasmania. Brilliant Creek and Golconda are intrusion-related Au; Denison shows feature of both intrusion-related (IRG) and orogenic Au deposits; Lisle was a significant alluvial field probably derived from IRG; remainder of fields are orogenic Au (after Reed, 2002). 

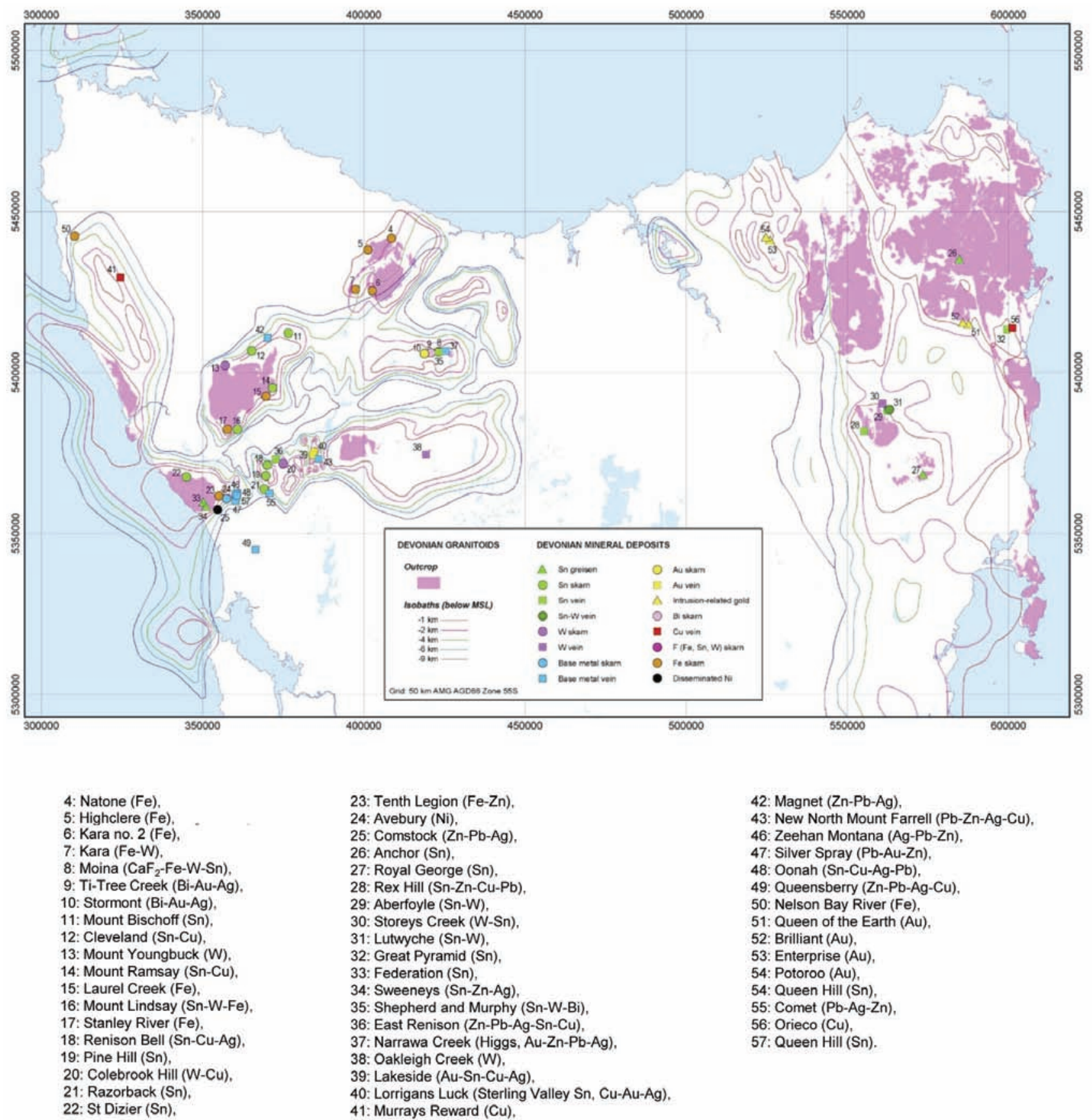

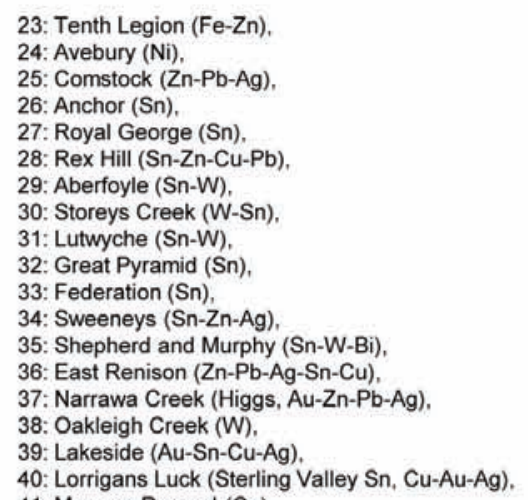

42: Magnet $(\mathrm{Zn}-\mathrm{Pb}-\mathrm{Ag})$

43: New North Mount Farrell ( $\mathrm{Pb}-\mathrm{Zn}-\mathrm{Ag}-\mathrm{Cu}$ ),

46: Zeehan Montana (Ag-Pb-Zn)

47: Silver Spray (Pb-Au-Zn),

48: Oonah (Sn-Cu-Ag-Pb),

49: Queensberry ( $\mathrm{Zn}-\mathrm{Pb}-\mathrm{Ag}-\mathrm{Cu})$,

50: Nelson Bay River (Fe),

51: Queen of the Earth (Au),

52: Brilliant (Au),

53: Enterprise (Au),

54: Potoroo (Au),

54: Queen Hill (Sn),

55: Comet (Pb-Ag-Zn),

56: Orieco $(\mathrm{Cu})$,

57: Queen Hill (Sn).

40: Lorrigans Luck (Sterling Valley Sn, Cu-Au-Ag),

41: Murrays Reward (Cu),

Figure 5 Location of significant Devonian granite related deposits (after Green et al., 2012) and Devonian granite isobaths (after Leaman and Richardson, 2003).

lithologies, and perhaps also to a greater degree of unroofing (Solomon and Groves, 1994). There is current exploration interest in intrusionrelated Au that occurs as part of the Au-As-Bi-Mo association within, and in the aureoles of, unfractionated I-type moderately oxidised to moderately reduced granodiorite in the Lisle-Golconda area. Significant mineral deposits (Figure 5) are cassiterite- and wolframitebearing vein deposits (e.g., Aberfoyle and Storeys Creek) and Snbearing greisen deposits associated with post-tectonic reduced, strongly fractionated, S-type granite (e.g. Anchor and Royal George). Base metal vein deposits are known but are insignificant. Kaolinite is found in the haloes of greisen Sn deposits and within alluvial Sn deposits. Kaolinite of debatable hydrothermal or supergene origin from Tonganah, near Scottsdale, has been exploited as paper filler.
In contrast, western Tasmania contains a wide variety of reactive host rocks including dolomite, limestone and ultramafic rocks. This has led to a much more diverse suite of deposit styles, the most important of which are sulfide and silicate skarns.

World-class calcic scheelite skarns on King Island (Dolphin and Bold Head) are in the contact aureole of I-type, moderately oxidised unfractionated granodiorite (Kwak, 1987; Solomon and Groves, 1994), whereas at the Kara deposit calcic magnetite-scheelite-bearing skarn abuts moderately fractionated, moderately to strongly oxidised granite (Zaw and Singoyi, 2000). Calcic magnetite-fluorite skarn with minor $\mathrm{Sn}$ and $\mathrm{W}$ is associated with strongly fractioned, moderately reduced I-type granite at Moina, where there are also distal $\mathrm{Au} \pm \mathrm{Bi} \pm$ $\mathrm{Cu}$ skarns (Figure 5). 
Distal sulfide skarn Sn deposits (Renison Bell, Mount Bischoff, Cleveland, Queen Hill and Razorback; Figure 5) are the most economically important and the former two, both world-class deposits, are associated with reduced, moderately to strongly fractionated Itype granite. Fracture filling quartz-arsenopyrite-pyrrhotitecassiterite-fluorite veins occupy faults that were active during ore formation at Renison Bell. These were the hydrothermal feeders to the dolomite-replacement pyrrhotite cassiterite horizons (Kitto, 1994; Patterson et al., 1981) that have been the dominant source of ore. At Mount Bischoff, cassiterite-bearing greisenised quartz porphyry dykes were the conduits for ore formation and form a significant part of the Sn resource (Halley and Walshe, 1995; Solomon and Groves, 1994). At the Cleveland mine the subeconomic dyke-hosted deposit (Foley's Zone) contains significant Mo, W and Bi as well as Sn (Collins, 1981; Jackson, 1992) and also appears to have been a fluid conduit.

Tin silicate skarns lie in the immediate contact zones of reduced, fractionated I-type and indeterminate-type granites. These deposits may be metallurgically difficult depending upon the partitioning of Sn between cassiterite and a variety of silicate, oxide and borate minerals (Kwak, 1987). The most important proximal deposits are the Mt Lindsay (Figure 5) and nearby magnetite-cassiterite-scheelitebearing skarns, on which a full feasibility study is currently being undertaken.

Granites associated with Sn mineralisation contain evidence of a component of mantle melts and volatiles (e.g., Sun and Higgins, 1996; Solomon and Groves, 1994; Walshe et al., 1996), which may have been related to mafic underplating of the crust associated with postcollisional slab break-off (Black et al., 2010).

The most unusual deposit is the Avebury Ni deposit, which lies in the aureole of the strongly fractionated, reduced Heemskirk white granite (Figure 5). There is debate on whether it is a skarn or a hydrothermally-altered more conventional type of magmatic $\mathrm{Ni}$ deposit. Disseminated Ni mineralisation, mostly as pentlandite, occurs within Cambrian serpentinite adjacent to structurally overlying basalt and mudstone-lithicwacke-minor carbonate sequences. There are two main gangue assemblages; antigorite-magnetite-chromite and tremolite-diopside-magnetite, both with pentlandite- pyrrhotitemillerite-arsenides (Callaghan and Green, cited in Green et al., 2012). Keays et al. (2009) showed that there was positive correlation of $\mathrm{Ni}$ with Pd and Au contents in mineralised ultramafics, but there was an apparent negative correlation between $\mathrm{Ni}$ and $\mathrm{Ir}$ and no correlation between Pt and Ni. These features are consistent with Au and Pd being added to the ores together with $\mathrm{Ni}$ in the same Devonian metasomatic event. Lygin et al. (2010a, b) provided further evidence for a hydrothermal origin, including a lack of PGE inclusions in pentlandite and pyrrhotite and contamination of these minerals with $\mathrm{Pb}, \mathrm{Bi}$ and $\mathrm{As}$, both in fine grained mineral inclusions and incorporated in the sulfide structures. Chrome spinels are strongly altered and are veined and partly rimmed and replaced by magnetite and chrome magnetite. Boundaries between $\mathrm{Cr}$-spinel cores and $\mathrm{Cr}$-magnetite or magnetite overgrowths are commonly marked by the presence of $\mathrm{Si}$, $\mathrm{Pb}, \mathrm{Sb}$ and locally $\mathrm{Cu}$. Magnetite is intimately associated with pentlandite and is relatively enriched in $\mathrm{Sn}$, pointing to a hydrothermal origin. Altered $\mathrm{Cr}$-spinel has lower $\mathrm{Cr} /(\mathrm{Cr}+\mathrm{Al})$ ratios and may be enriched in $\mathrm{Zn}$ and $\mathrm{Mn}$. Whole rock geochemistry indicates that, while incompatible trace element contents in the ultramafic are very low, there are distinct positive anomalies for $\mathrm{W}, \mathrm{U}, \mathrm{Pb}, \mathrm{Bi}, \mathrm{Mo}, \mathrm{Sn}$ and $\mathrm{Sb}$ when data are plotted on a primitive mantle-normalised spidergram.
Tin greisen (e.g., Sweeneys and Federation) and vein deposits of $\mathrm{Sn}$ (Pieman vein at East Renison), W (Oakleigh Creek), $\mathrm{Cu}$ (Murrays Reward), and $\mathrm{Pb}-\mathrm{Ag}-\mathrm{Zn} \pm \mathrm{Au}$ (Magnet, Zeehan and Mount Farrell fields; Figure 5) were historically important producers in western Tasmania and are currently being explored. Conspicuous haloes occur around the reduced, fractionated granites associated with $\mathrm{Sn}$ mineralisation, but are relatively rare around the moderately or unfractionated granites with marginal scheelite skarns.

The movement of mineralising fluids outward from the granitic intrusions to favourable sites for ore formation was assisted by the complex pre-existing network of major faults which was largely the net result of Cambrian and Devonian orogenesis. Mineralised structures were initiated or reactivated at the time of granite emplacement and occur in a variety of settings including fractures formed in a regional stress field above granite cupolas (Zeehan Pb$\mathrm{Ag}-\mathrm{Zn}$ veins) or ridges (Lakeside and Mount Farrell field), faults tangential to margins of granite intrusions (Aberfoyle and Renison Bell) and porphyry dykes that also acted as hydrothermal conduits and form a radiating array above an inferred granite cupola (Mount Bischoff).

\section{Post Devonian}

Large-scale erosion followed the close of Devonian orogenesis. Deposition restarted in the late Carboniferous with $1.5 \mathrm{~km}$ of generally flat-lying sedimentary rocks of late Carboniferous-Late Triassic age deposited in the Tasmania Basin. These consist of a lower glacial and glaciomarine and subordinate terrestrial sedimentary rocks, overlain by fluvial and lacustrine sedimentary rocks, largely of Triassic age. Both units contain subordinate coal measures (Seymour et al., 2006). Large volumes of Jurassic dolerite, in the form of slightly discordant sheets and dykes crop out over a large part of Tasmania and contribute to its scenery. A Cretaceous felsic alkaline porphyry complex at Cygnet in southeast Tasmania is associated with minor $\mathrm{Au}$ mineralisation (Taheri and Bottrill, 1999).

Paleocene weathering produced Ni laterite deposits near Beaconsfield, which are the subject of a feasibility study. Placer Sn deposits have been a significant contributor to the economy of northeastern Tasmania. The bulk of production has come from upper Oligocene braidplain deposits around the southeastern edge of the Ringarooma Valley (Morrison, 1989).

Paleogene and Neogene basalt flows are widespread. Alluvial heavy minerals, including rutile and zircon, have been mined from Pleistocene strandlines on King Island, and production is currently being revived.

\section{Acknowledgements}

Thoughtful reviews by David Huston and Ken McQueen resulted in substantial improvements to the manuscript.

\section{References}

Allen, R.L., 1995, Synvolcanic, subseafloor replacement model for Rosebery and other massive sulphide ores, in Cooke, D.R. and Kitto, P.A. (ed), Contentious issues in Tasmanian geology: Geological Society of Australia, Abstracts 39, pp. 107-108.

Banks, M.R. and Baillie, P.W., 1989, Late Cambrian to Devonian, in Burrett, C.F. and Martin, E.L. (eds), Geology and mineral resources of Tasmania: 
Geological Society of Australia, Special Publication 15, pp. 182-237.

Banks, M.R. and Burrett, C.F., 1980, A preliminary Ordovician biostratigraphy of Tasmania. Journal of the Geological Society of Australia, v. 26, pp. 363-376.

Berry, R.F. and Crawford, A.J., 1988, The tectonic significance of Cambrian allochthonous mafic-ultramafic complexes in Tasmania: Australian Journal of Earth Sciences, v. 35, pp. 523-533.

Berry, R.F., Holm, O.H. and Steele, D.A. 2005. Chemical U-Th-Pb dating and the Proterozoic history of King Island, southeast Australia: Australian Journal of Earth Sciences, v. 52, pp. 461-471.

Bierlein, F.P., Foster, D.A., Gray, D.R. and Davidson, G.J., 2005, Timing of orogenic gold mineralisation in northeastern Tasmania: implications for the tectonic and metallogenic evolution of Palaeozoic SE Australia: Mineralium Deposita, v. 39, pp. 890-903.

Black, L.P, Seymour, D.B., Corbett, K.D., Cox, S.E., Streit, J.E., Bottrill, R.S., Calver, C.R., Everard, J.L., Green, G.R., McClenaghan, M.P., Pemberton, J., Taheri, J. and Turner, N.J., 1997, Dating Tasmania's oldest geological events: Australian Geological Survey Organisation, Record 1997/15.

Black, L.P., Calver, C.R., Seymour, D. B. and Reed, A., 2004, SHRIMP U$\mathrm{Pb}$ detrital zircon ages from Proterozoic and Early Palaeozoic sandstones and their bearing on the early geological evolution of Tasmania: Australian Journal of Earth Sciences, v. 51, pp. 885-900.

Black, L.P., McClenaghan, M.P., Korsch, R.J., Everard, J.L., and Foudoulis, C., 2005, Significance of Devonian-Carboniferous igneous activity in Tasmania as derived from U-Pb SHRIMP dating of zircon: Australian Journal of Earth Sciences, v. 52, pp. 807-829.

Black, L.P., Everard, J.L., McClenaghan, M.P., Korsch, R.J., Calver, C.R., Fioretti, A.M., Brown, A.V. and Foudoulis, C., 2010, Controls on Devonian-Carboniferous magmatism in Tasmania, based on inherited zircon age patterns, $\mathrm{Sr}, \mathrm{Nd}$ and $\mathrm{Pb}$ isotopes, and major and trace element geochemistry: Australian Journal of Earth Sciences, v. 57, pp. 933-968.

Bottrill, R. S. and Taheri, J., 2008, Petrology of the host rocks, including mineralisation and adjacent rock sequences, from the Savage River mine: Tasmanian Geological Survey, Record 2007/5.

Brown, A.V. and Jenner, G.A., 1989, Geological setting, petrology and chemistry of Cambrian boninite and low Ti-tholeiite lavas in western Tasmania, in Crawford, A.J. (ed), Boninites and related rocks: Unwin Hyman, London, pp. 232-263.

Callaghan, T., 2001, Geology and host-rock alteration of the Henty and Mount Julia gold deposits, western Tasmania: Economic Geology, v. 96, pp. 1073-1088.

Calver, C.R., Everard, J.L., Berry, R.F., Bottrill, R.S. and Seymour, D.B., 2012, Proterozoic Tasmania, in Corbett, K.D., Quilty, P.G. and Calver, C.R. (eds), The Geological Evolution of Tasmania: Geological Society of Australia, Special Publication (in press).

Collins, P.L.F., 1981, The geology and genesis of the Cleveland tin deposit, western Tasmania: Fluid inclusion and stable isotope studies: Economic Geology, v. 76, pp. 365-392.

Corbett, K.D., 1992, Stratigraphic-volcanic setting of massive sulfide deposits in the Cambrian Mount Read Volcanics, Tasmania: Economic Geology, v. 87 , pp. $564-586$

Corbett, K.D., 2001, New mapping and interpretations of the Mount Lyell mining district, Tasmania: A large hybrid $\mathrm{Cu}-\mathrm{Au}$ system with an exhalative Pb-Zn top: Economic Geology, v. 96, pp. 1089-1122.

Corbett, K.D., 2002, Western Tasmanian Regional Minerals Program. Mount Read Volcanics Compilation. Updating the geology of the Mount Read Volcanics belt: Tasmanian Geological Survey, Record 2002/19.

Corbett, K.D. and Vicary, M.J., 2012, Middle Cambrian post-collisional volcanism and sedimentation, in Corbett, K.D., Quilty, P.G. and Calver, C.R. (eds), The Geological Evolution of Tasmania: Geological Society of Australia, Special Publication (in press).

Gee, R.D., 1967, The Proterozoic rocks of the Rocky Cape geanticline, in The geology of western Tasmania - a symposium: University of Tasmania, Hobart.

Gemmell, J.B. and Large, R.R., 1992, Stringer system and alteration zones underlying the Hellyer volcanogenic massive sulfide deposit, Tasmania, Australia: Economic Geology, v. 87, pp. 620-649.

Gifkins, C.C. and Kimber, B., 2003, 3-D geological modelling and mineral systems in Tasmania. Explanatory notes for the map of volcanic facies associations and volcanic centres in the Mount Read Volcanics, Tasmania: Centre for Ore Deposit Research, University of Tasmania (unpublished).

Green, G.R. and Taheri, J., 1992, Stable isotopes and geochemistry as exploration indicators: Tasmanian Geological Survey, Bulletin, v. 70, pp. 84-91.

Green, G.R., Solomon, M. and Walshe, J.L., 1981, The formation of the Rosebery volcanic-hosted massive sulfide ore deposit at Rosebery, Tasmania: Economic Geology, v. 76, pp. 304-338.

Green, G.R., Berry, R.F., Callaghan, T., Davidson, G.J. and Hills, P.B., 2012, Devonian mineralisation in Tasmania, in Corbett, K.D., Quilty, P.G. and Calver, C.R. (eds), The Geological Evolution of Tasmania: Geological Society of Australia, Special Publication (in press).

Halley, S.W., 2007, SWIR study of alteration mineralogy at Mount Julia (Henty): http://nvcl.csiro.au/Report.aspx? reportid=427

Halley, S.W. and Walshe, J.L., 1995, A reexamination of the Mount Bischoff cassiterite sulfide skarn, western Tasmania: Economic Geology, v. 90, pp. 1676-1693.

Herrmann, W. and Kimber, B., 2003, Map of altered facies in the Mount Read Volcanics, Tasmania: Centre for Ore Deposit Research, University of Tasmania (unpublished).

Holm, O.H. and Berry, R.F., 2002, Structural history of the Arthur Lineament, northwest Tasmania: an analysis of critical outcrops: Australian Journal of Earth Sciences, v. 49, pp. 167-185.

Huntington, J. and Cocks, T., 2003, Mt Lyell Hymap Survey: CSIRO/Hyvista Report (unpublished).

Huston, D.L. and Kamprad, J., 2001, Zonation of alteration facies at Western Tharsis: Implications for the genesis of $\mathrm{Cu}-\mathrm{Au}$ deposits, Mount Lyell field, western Tasmania: Economic Geology, v. 96, pp. 1123-1132.

Huston, D.L., Kositcin, N. and Champion, D.C., 2009, Part 3. Metallogenic events in Phanerozoic eastern Australia: Geoscience Australia, Record 2009/18, pp. 138-222.

Jackson, P. 1992, The evolution of Foley's Zone, Cleveland Mine, Tasmania, Sn-Mo-Bi mineralization, geology, petrology, fluid inclusions and stable isotopes: $\mathrm{PhD}$ thesis, LaTrobe University (unpublished).

Keays, R.R., Jowitt, S.M. and Callaghan, T., 2009, The Avebury Ni deposit, Tasmania: a case study of an unconventional nickel deposit, in Proceedings of the 10th Biennial SGA Meeting, 17th-20th August 2009, Townsville, Australia, v. 1, pp. 173-175.

Keele, R.A., 1994, Structure and veining in the Devonian-aged MathinnaAlberton gold lineament, northeast Tasmania: Mineral Resources Tasmania, Report 1994/06

Kitto, P.A., 1994, Structural and geochemical controls on mineralisation at Renison, Tasmania. PhD thesis, University of Tasmania (unpublished).

Kwak, T.A.P., 1987. W-Sn deposits and related metamorphic skarns and granitoids: Developments in Economic Geology 24, Elsevier.

Large, R.R., Doyle, M.G., Raymond, O.L., Cooke, D.R., Jones, A.T. and Heasman, L., 1996, Evaluation of the role of Cambrian granites in the genesis of world class VHMS deposits in Tasmania: Ore Geology Reviews, v. 10 , pp. $215-230$.

Laurie, J.R., 1995, Examination of macrofossils from the Pioneer Beds from near Queenstown, Tasmania: Australian Geological Survey Organisation, Professional Opinion, 1995/018.

Leaman, D.E. and Richardson, R.G., 2003, A geophysical interpretation of the major Tasmanian granitoids: Mineral Resources Tasmania, Report, 2003/11

Lygin, A.V., Foster, J.G., Hutchison, D. and Callaghan, T., 2010a, The mineralogy and geochemistry of the Avebury Ni-deposit, western Tasmania, in $13^{\text {th }}$ Quadrennial IAGOD Symposium, April 2010, Adelaide, South Australia, Abstracts, pp. 96-97.

Lygin, A.V., Foster, J.G. and Hutchison, D., 2010b, A new style of Nimineralization resulting from the interaction of ultramafic rocks with hydrothermal fluids derived from granites: Avebury Ni-deposit, western 
Tasmania, in $11^{\text {th }}$ International Platinum Symposium: Ontario Geological Survey, Miscellaneous Release-Data 269.

Meffre, S., Berry, R.F. and Hall, M., 2000, Cambrian metamorphic complexes in Tasmania: tectonic implications: Australian Journal of Earth Sciences, v. 47 , pp. $971-985$.

Morrison, K.C., 1989, Tin fields of northeastern Tasmania, in Burrett, C.F. and Martin, E.L. (eds), Geology and mineral resources of Tasmania: Geological Society of Australia, Special Publication, v. 15, p. 369.

Morrison, K.C. 2002, Western Tasmanian Regional Minerals Program. Mount Read Volcanics Compilation. Report on field investigations, Mt DarwinMt Murchison region: Tasmanian Geological Survey, Record, 2002/18.

Murphy, F.C., Denwer, K., Keele, R.A., Stapleton, P., Seymour, D.B. and Green, G.R., 2004, Tasmania mineral province: geoscientific database, 3D geological modelling, mines and mineral prospectivity: Mineral Resources Tasmania (unpublished).

Noll, C.A. and Hall, M., 2005, Structural architecture of the Owen Conglomerate, West Coast Range, western Tasmania: field evidence for Late Cambrian extension: Australian Journal of Earth Sciences, v. 52, pp. 411-426.

Patterson, D. J., Ohmoto, H. and Solomon, M., 1981, Geologic setting and genesis of cassiterite-sulfide mineralization at Renison Bell, western Tasmania: Economic Geology, v. 76, pp. 393-438.

Pemberton, J. and Corbett, K.D., 1992, Stratigraphic-facies associations and their relationship to mineralisation in the Mount Read Volcanics: Tasmanian Geological Survey, Bulletin, v. 70, pp. 167-176.

Powell, C. McA., 1991, Structure of the Beaconsfield and Lefroy goldfields: Mines and Mineral Resources Tasmania, Report, 1991/16.

Reed, A.R., 2001, Pre-Tabberabberan deformation in eastern Tasmania: a southern extension of the Benambran Orogeny: Australian Journal of Earth Sciences, v. 48, pp. 785-796.

Reed, A.R., 2002, Formation of lode-style gold mineralisation during Tabberabberan wrench faulting at Lefroy, eastern Tasmania: Australian Journal of Earth Sciences 49:879-890.

Reed, A.R., 2004, Gold mineralisation and the regional Palaeozoic structure of the Mathinna Supergroup, eastern Tasmania: Tasmanian Geological Survey, Record, 2004/1.

Seymour, D.B., Green, G.R. and Calver, C.R., 2006, The geology and mineral deposits of Tasmania: a summary: Tasmanian Geological Survey, Bulletin, v. 72.

Seymour, D.B., Woolward, I.R., McClenaghan, M.P. and Bottrill, R.S., 2011, Stratigraphic revision and re-mapping of the Mathinna Supergroup between the Tamar River and the Scottsdale Batholith, northeast Tasmania: Mineral Resources Tasmania, Explanatory Report 1:25000 Scale Digital Geological Map Series 4.
Solomon, M. and Groves, D.I., 1994, The geology and origin of Australia's mineral deposits: Oxford University Press.

Solomon, M. and Groves, D.I., 2000, The geology and origin of Australia's mineral deposits, reprinted with additional material: Centre for Ore Deposit Research, University of Tasmania and Centre for Global Metallogeny, University of Western Australia.

Solomon, M., Vokes, F.M. and Walshe, J.L., 1987, Chemical remobilization of volcanic-hosted massive sulphide deposits at Rosebery and Mt Lyell, Tasmania: Ore Geology Reviews, v. 2, pp. 173-190.

Sun, S.-S. and Higgins, N.C., 1996, Neodymium and strontium isotope study of the Blue Tier Batholith, NE Tasmania, and its bearing on the origin of tin-bearing alkali feldspar granites: Ore Geology Reviews, v. 10, pp. 339365 .

Taheri, J. and Bottrill, R.S., 1999, Porphyry and sediment-hosted gold deposits near Cygnet: new styles of gold mineralisation in Tasmania: Tasmanian Geological Survey, Record, 1999/01.

Taylor, S. and Mathison, I.J., 1990. Oceana lead-zinc-silver deposit, in Hughes, F.E. (ed), Geology of the mineral deposits of Australia and Papua New Guinea: The Australasian Institute of Mining and Metallurgy, Monograph, v. 14 , pp. $1253-1256$.

Turner, N.J., Black, L.P. and Higgins, N.C., 1986, The St Marys Porphyrite a Devonian ash-flow tuff and its feeder: Australian Journal of Earth Sciences, v. 33, pp. 201-218.

Turner, N.J., Brown, A.V., McClenaghan, M.P. and Soetrisno, I.R., 1991, Geological atlas 1:50 000 series. Sheet 43 (7914N). Corinna: Mines and Mineral Resources Tasmania.

Turner, N.J., Black, L.P. and Kamperman, M, 1998, Dating of Neoproterozoic and Cambrian orogenies in Tasmania: Australian Journal of Earth Sciences, v. 45, pp. 789-806.

Walshe, J.L. and Solomon, M., 1981, An investigation into the environment of formation of the volcanic-hosted Mt Lyell copper deposits using geology, mineralogy, stable isotopes, and a six-component chlorite solidsolution model: Economic Geology, v. 76, pp. 246-284.

Walshe, J.L., Halley, S.W., Anderson, J.A. and Harrold, B.P., 1996. The interplay of groundwater and magmatic fluids in the formation of the cassiterite-sulfide deposits of western Tasmania: Ore Geology Reviews, v. 10, pp. $367-387$.

White, M.J. and McPhie, J., 1996, Stratigraphy and palaeovolcanology of the Cambrian Tyndall Group, Mt Read Volcanics, western Tasmania: Australian Journal of Earth Sciences, v. 43, pp. 147-159.

Zaw, K. and Singoyi, B., 2000, Formation of magnetite-scheelite skarn mineralization at Kara, northwestern Tasmania: Evidence from mineral chemistry and stable isotopes: Economic Geology, v. 95, pp. 1215-1230.

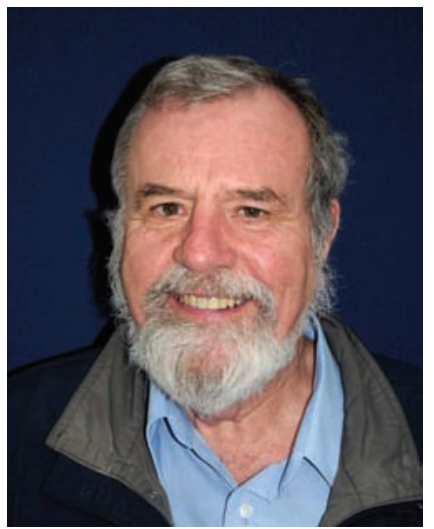

Geoff Green holds First Class Honours and PhD degrees in mineral deposits geology from the University of Tasmania. He has worked for Mineral Resources Tasmania and predecessor agencies for most of his 42 year career, apart from 4 years as a Research Associate at the Pennsylvania State University working on volcanic-hosted massive sulfide deposits. He is currently Managing Geologist - Metallic Minerals and Geochemistry at Mineral Resources Tasmania responsible for a wide range of activities particularly acquisition of geological data relevant to metallic mineral resources and promotion of mineral exploration opportunities. 